\title{
On the Solid, Liquid and Solution Structural Organization of Imidazolium Ionic Liquids
}

\author{
Jairton Dupont \\ Instituto de Química, Universidade Federal do Rio Grande do Sul, Av. Bento Gonçalves, 9500, 91501-970 \\ Porto Alegre - RS Brazil
}

\begin{abstract}
Sais derivados do cátion 1,3-dialquilimidazólio são uma das mais populares e investigadas classes de líquidos iônicos a temperatura ambiente. Embora, em vários casos, suas propriedades físico-químicas e/ou o resultado dos processos que ocorrem nesses líquidos diferem significantemente daqueles obtidos em solventes orgânicos dipolares, estes ainda podem ser descritos como simples solventes orgânicos. Nesta revisão, será introduzido o conceito que líquidos iônicos derivados do cátion 1,3-dialquilimidazólio são mais convenientemente descritos como estruturas poliméricas supramoleculares do tipo $\left.\left.\left\{\left[(\mathrm{DAI})_{\mathrm{x}}(\mathrm{X})_{\mathrm{x}-\mathrm{n}}\right)\right]^{\mathrm{n}+}\left[(\mathrm{DAI})_{\mathrm{x}-\mathrm{n}}(\mathrm{X})_{\mathrm{x}}\right)\right]^{\mathrm{n}-}\right\}_{\mathrm{n}}$ onde DAI representa o cátion 1,3dialquilimidazólio e $\mathrm{X}$ o ânion. Este padrão estrutural é observado geralmente em sólidos e mantido em grande extensão no estado líquido e mesmo em fase gasosa. A introdução de outras moléculas ou macromoléculas no líquido iônico provoca a perturbação da rede de ligações de hidrogênios podendo gerar, em alguns casos, nano-estruturas com regiões polares e apolares onde compostos de inclusão podem ser formados.
\end{abstract}

1,3-dialkyl imidazolium salts are one of the most popular and investigated classes of room temperature ionic liquids. Although in various cases the physical-chemical properties and/or the outcome of the processes in these liquids significantly differ from those performed in "classical" dipolar organic solvents, they are still regarded as merely homogeneous solvents. In this brief overview it is developed the concept that pure 1,3-dialkylimidazolium ionic liquids are better described as hydrogen-bonded polymeric supramolecules of the type $\left.\left.\left\{\left[(\mathrm{DAI})_{\mathrm{x}}(\mathrm{X})_{\mathrm{x}-\mathrm{n}}\right)\right]^{\mathrm{n}+}\left[(\mathrm{DAI})_{\mathrm{x}-\mathrm{n}}(\mathrm{X})_{\mathrm{x}}\right)\right]^{\mathrm{n}-}\right\}_{\mathrm{n}}$ where DAI is the 1,3-dialkylimidazolium cation and $\mathrm{X}$ the anion. This structural pattern is a general trend for the solid phase and is maintained to a great extent in the liquid phase and even in the gas phase. The introduction of other molecules and macromolecules occurs with a disruption of the hydrogen bond network and in some cases can generate nano-structures with polar and non-polar regions where inclusion-type compounds can be formed.

Keywords: ionic liquids; molten salts, supramolecules, nano-materials, solvents, clusters

\section{Introduction}

Soon after the first reports on the syntheses and applications in organometallic catalysis of the air stable room temperature ionic liquids (RTILs) 1-n-butyl-3methylimidazolium tetrafluoroborate $\left(\mathrm{BMI}_{\mathrm{B}} \mathrm{BF}_{4}\right)$, hexafluorophosphate (BMI.PF ${ }_{6}$ ) and their analogues ${ }^{1}$ in the middle of the 1990s a renaissance of the rich chemistry of molten salts ${ }^{2}$ has begun and continues to flourish. 1,3Dialkylimidazolium cations associated with relatively weak coordinating anions such as tetrafluoroborate, hexafluorophosphate, trifluoromethane sulfonate, etc. (Figure 1) are compounds with unique physical-chemical properties: they are liquids over a large range of

*e-mail: dupont@iq.ufrgs.br temperatures (down to $-80^{\circ} \mathrm{C}$ ), posses high thermal and chemical stability, large electrochemical window (up 7V), high density, relatively low viscosity and negligible vapor pressure (Table 1). ${ }^{3}$

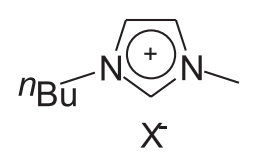

$$
\begin{aligned}
& \mathrm{X}=\mathrm{BF}_{4}, \mathrm{BMI} . \mathrm{BF}_{4} \\
& \mathrm{X}=\mathrm{PF}_{6},{\mathrm{BMI} . P F_{6}} \\
& \mathrm{X}=\mathrm{CF}_{3} \mathrm{SO}_{3},{\mathrm{BMI} . \mathrm{CF}_{3} \mathrm{SO}_{3}} \\
& \mathrm{X}=\mathrm{NTf}_{2}, \mathrm{BMI} . \mathrm{NTf}_{2}
\end{aligned}
$$

Figure 1. Examples of 1,3-dialkylimidazolium ionic liquids.

The physical-chemical properties of these materials can, in principle, be finely tuned by varying the Nalkylimidazolium substituents and/or the anion (Table 1). Most of the imidazolium ionic liquids are now commercially available from several suppliers and their synthesis is part of classical organic syntheses. ${ }^{4}$ 
These materials are very popular and enjoy a plethora of applications in various domains of physical sciences. For example, they are used as "solvents" for organic, organometallic syntheses and catalysis, ${ }^{5}$ as electrolytes in electrochemistry, in fuel ${ }^{6}$ and solar cells, ${ }^{7}$ as lubricants, ${ }^{8}$ as a stationary phase for chromatography, ${ }^{9}$ as matrices for mass spectrometry, ${ }^{10}$ supports for the immobilization of enzymes, ${ }^{11}$ in separation technologies, ${ }^{12}$ as liquid crystals,${ }^{13}$ templates for the synthesis of mesoporous, ${ }^{14}$ nano-materials ${ }^{15}$ and ordered films, ${ }^{16}$ materials for embalming and tissue preservation, ${ }^{17}$ etc. Not surprisingly an impressive number of specialized reviews ${ }^{5}$ and books ${ }^{18}$ have recently appeared dealing with their synthesis, physical-chemical properties and applications. Moreover, significant and indispensable theoretical works have been recently performed in order to rationalize their structure and physical-chemical properties. ${ }^{19}$ In the vast majority of these studies imidazolium ionic liquids are regarded as merely homogeneous "solvents" and their properties as generally compared with those of classical "polar" organic solvents. In this respect, several attempts have been made in order to apply the classical parameters generally employed for the description of molecular solvents such as "polarity" (dielectric constant) and coordinating properties for ionic liquids have met little success. However, in many instances, the outcome of the reactions or physical properties studied in these liquids strongly differs from those performed or investigated in "classical" organic solvents.

This brief overview will concentrate on the development of the concept that "pure" imidazolium ionic liquids can be described as polymeric hydrogen-bonded supramolecules (highly ordered hydrogen bonded materials) and in some cases when mixed with other molecules they should be better regarded as nanostructured materials with polar and non-polar regions rather than homogeneous solvents. Nano-structured material can be defined as materials with atoms arranged in nanosized clusters, which become the constituent grains or building blocks of the material. ${ }^{25}$

\section{Structural Organization in Solid Phase}

Ionic liquids can be defined as electrolytes composed entirely of ions that are liquid at temperatures close to room temperature. Although most used and preferred ionic liquids are those that are liquid at room temperature (Figure 1) detailed structural features are easily accessible by looking at those that crystallize and that have their crystal structure determined. A simple comparison of these data can yield important information about the structural features of the same material in the liquid phase. An over view in the X-ray studies reported in the last years on the structure of 1,3-dialkylimidazoilum salts ${ }^{26}$ reveals a typical trend: they form in the solid state an extended network of cations and anions connected together by hydrogen bonds. The monomeric unit is always constituted of one imidazolium cation surrounded by at least three anions and in turn each anion is surrounded by at least three imidazolium cations (Figure 2). The strongest hydrogen bond always involves the most acidic $\mathrm{H} 2$ of the imidazolium cation $\left(\mathrm{p} K_{\mathrm{a}}=23.0\right.$ for the 1,3-dimethyl imidazolium cation ${ }^{27}$ followed by the other two hydrogens ( $\mathrm{H} 4$ and $\mathrm{H} 5)$ of the imidazolium nucleus and/ or the hydrogens of the $\mathrm{N}$-alkyl radicals (H6, H7 and $\mathrm{H} 8$, Table 2). These bonds possess properties of weak to moderate hydrogen bonds - they are mostly electrostatic in nature $-\left(\mathrm{H}^{\cdots \cdots} \cdot \mathrm{X}\right.$ bond lengths $>2.2 \AA$; $\mathrm{C}-\mathrm{H}^{\cdots \cdots} \cdot \mathrm{X}$ bond angles between $\left.100^{\circ}-180^{\circ}\right) .^{28}$

Although the number of anions that surround the cation (and vice-versa) can change depending upon the anion size and type of the $\mathrm{N}$-alkyl imidazolium substituents, the structural trend of one imidazolium hydrogen bonded to at least three anions and one anion hydrogen bonded to at least three cations is a general trend in imidazolium salts (for examples see Table 2).

Table 1. Selected physical chemical data of some 1-alkyl-3-methylimidazolium based ionic liquids

\begin{tabular}{|c|c|c|c|c|c|c|c|c|}
\hline $\mathrm{R}$ & $\mathrm{X}$ & $\operatorname{Tg}^{\mathrm{a}}\left({ }^{\circ} \mathrm{C}\right)$ & $\operatorname{Tm}^{\mathrm{b}}\left({ }^{\circ} \mathrm{C}\right)$ & $\mathrm{Td}^{\mathrm{c}}\left({ }^{\circ} \mathrm{C}\right)$ & $\eta(\mathrm{mPa} \mathrm{s})^{\mathrm{d}}$ & $d\left(\mathrm{~g} \mathrm{~cm}^{-3}\right)^{\mathrm{e}}$ & $\sigma\left(\mathrm{mScm}^{-1}\right)^{\mathrm{f}}$ & Ref. \\
\hline Et & $\mathrm{BF}_{4}$ & -92 & 13 & 447 & 37 & 1.28 & 14 & 20 \\
\hline${ }^{n} \operatorname{Pr}$ & $\mathrm{BF}_{4}^{4}$ & -88 & -17 & 435 & 103 & 1.24 & 5.9 & 20 \\
\hline${ }^{n} \mathrm{Bu}$ & $\mathrm{BF}_{4}^{4}$ & -85 & none & 435 & $180(233)$ & 1.21 & $3.5(8.6)$ & 3,20 \\
\hline${ }^{n} \mathrm{Bu}$ & $\mathrm{PF}_{6}$ & -61 & 10 & - & $219(312)$ & 1.37 & $1.6(6.5)$ & 3,21 \\
\hline${ }^{n} \mathrm{Bu}$ & $\mathrm{AlCl}_{4}$ & -88 & none & - & (294) & 1.23 & $(24.1)$ & 22 \\
\hline${ }^{n} \mathrm{Bu}$ & $\mathrm{CF}_{3} \mathrm{SO}_{3}$ & - & 16 & - & 90 & 1.22 & 3.7 & $1 \mathrm{c}$ \\
\hline${ }^{n} \mathrm{Bu}$ & $\mathrm{N}(\mathrm{Tf})_{2}$ & - & -4 & $>400$ & 69 & 1.43 & 3.9 & $1 c, 23$ \\
\hline${ }^{n} \mathrm{Bu}$ & $\mathrm{CF}_{3} \mathrm{CO}_{2}$ & -30 & none & - & 73 & 1.21 & 3.2 & $1 \mathrm{c}$ \\
\hline \multicolumn{2}{|c|}{ Ethylene glycol none } & -13 & $196^{\mathrm{g}}$ & 21 & 1.11 & - & 24 & \\
\hline
\end{tabular}

${ }^{a}$ Glass transition temperature, ${ }^{\mathrm{b}}$ Melting point, ${ }^{\mathrm{c}}$ Decomposition temperature, ${ }^{\mathrm{d}}$ Viscosity at $25{ }^{\circ} \mathrm{C}$ and in parenthesis at $30{ }^{\circ} \mathrm{C}$, ${ }^{\mathrm{e}}$ Density at $25{ }^{\circ} \mathrm{C}$,

${ }^{\mathrm{f}}$ Conductivity at $25^{\circ} \mathrm{C}$ and in parenthesis at $60{ }^{\circ} \mathrm{C}$, ${ }^{\mathrm{g}}$ boiling point. 
Note that even in the case $\mathrm{B}(\mathrm{Ar})_{4}$ anions the network is formed through relatively strong $\mathrm{C}-\mathrm{H} \cdots \pi$ hydrogen bonds. ${ }^{29}$

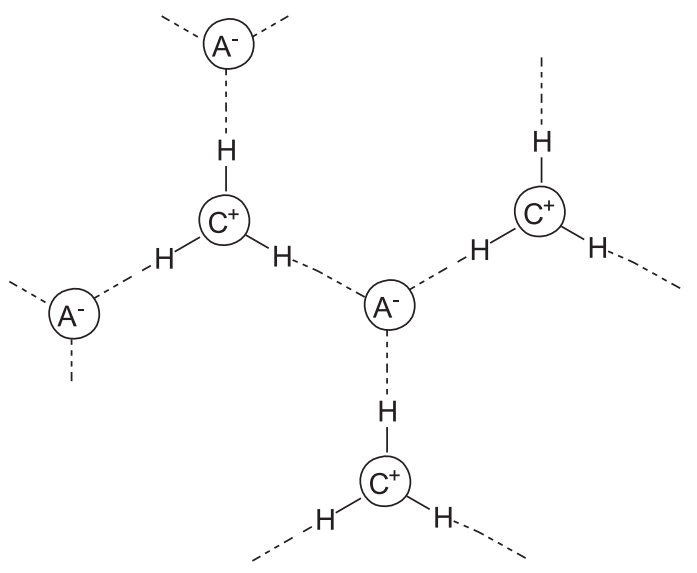

Figure 2. Two-dimensional simplified solid-state model of the polymeric supramolecular structure of 1,3-dialkyl imidazolium ionic liquids showing the hydrogen bonds between the imidazolium cation $(\mathrm{C})$ and the anions (A) (one cation is surrounded by three anions and vice-versa).
In the case of the octahedral $\mathrm{PF}_{6}$ anion the equatorial $\mathrm{F}$ atoms participate preferentially in hydrogen bonding network and in the case of the tetrahedral $\mathrm{BF}_{4}$ anion only three of the $\mathrm{F}$ atoms are usually involved in the linkage.

The three dimensional arrangement of the imidazolium ionic liquids are generally formed trough chains of the imidazolium rings (Figure 3 ). In some cases there are typical $\pi-\pi$ stacking interactions among the imidazolium rings and in the case of 1-alkyl-3-methylimidazolium salts a relatively weak $\mathrm{C}-\mathrm{H} \cdots \pi$ interactions via the methyl group and the imidazolium ring- $\pi$ system can be also found. This molecular arrangement can generate channels in which the spherical anions are accommodated as chains. This structural pattern depends on the anion geometry and the internal arrangements along the imidazolium columns vary with the type of the $\mathrm{N}$-alkyl substituents. Of note that other effects than $\pi-\pi$ stacking, such as the entropy effect and electrostatic interactions may not favorable the formation of structures of the type shown in Figure 3.

Therefore, it can be proposed that the best representation for the imidazolium salts in the solid phase

Table 2. Selected structural data for Imidazolium $\mathrm{H}$ bonded with various anions ( $\mathrm{H}$ bond distances in $\AA$ and bond angles in ${ }^{\circ}$ ). Only the anions that have significant interactions ${ }^{\text {a) }}$ with $\mathrm{H}$ of the imidazolium ring are shown

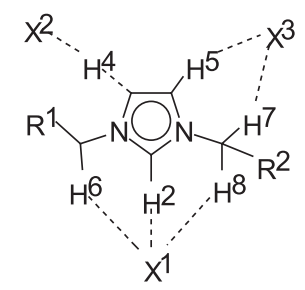

\begin{tabular}{|c|c|c|c|c|c|c|c|c|c|}
\hline $\mathrm{R}^{1}$ & $\mathrm{R}^{2}$ & $\mathrm{X}$ & $\mathrm{H}^{2}-\mathrm{X}^{1}$ & $\mathrm{H}^{4}-\mathrm{X}^{2}$ & $\mathrm{H}^{5}-\mathrm{X}^{3}$ & $\mathrm{H}^{7}-\mathrm{X}^{3}$ & $\mathrm{H}^{6}-\mathrm{X}^{1}$ & $\mathrm{H}^{8}-\mathrm{X}^{1}$ & Ref. \\
\hline $\mathrm{H}$ & $\mathrm{Me}$ & $\mathrm{Cl}\left(\mathrm{Cl}^{-}\right)^{\mathrm{b})}$ & 3.38 & 3.60 & 3.47 & & & & 30 \\
\hline \multirow[t]{2}{*}{$\mathrm{H}$} & ${ }^{n} \operatorname{Pr}$ & $\mathrm{Cl}\left(\mathrm{Cl}^{-}\right)$ & 2.517 & 2.882 & 2.995 & 2.760 & & & \\
\hline & & & 157.5 & 122.2 & 139.0 & 147.5 & & & 31,32 \\
\hline \multirow[t]{2}{*}{$\mathrm{H}$} & ${ }^{n} \operatorname{Pr}$ & $\mathrm{F}\left(\mathrm{F}^{-}\right)$ & 1.965 & 2.312 & 2.067 & & 2.745 & & \\
\hline & & & 160.2 & 139.3 & 174.9 & & 135.8 & & 33 \\
\hline \multirow[t]{2}{*}{$\mathrm{H}$} & $\mathrm{Me}$ & $\mathrm{Br}\left(\mathrm{Br}^{-}\right)$ & 2.775 & 2.886 & 2.967 & 2.996 & 3.201 & & \\
\hline & & & 150.3 & 164.0 & 152.6 & 137.6 & 151.2 & & 34 \\
\hline \multirow[t]{2}{*}{$\mathrm{H}$} & $\mathrm{Me}$ & $\mathrm{I}\left(\mathrm{I}^{-}\right)$ & 2.928 & 3.132 & 3.169 & 3.169 & 3.133 & & \\
\hline & & & 143.9 & 164.5 & 155.8 & 150.0 & 155.7 & & 34 \\
\hline \multirow[t]{2}{*}{$\mathrm{H}$} & ${ }^{n} \operatorname{Pr}$ & $\mathrm{Ar}\left(\mathrm{BPh}_{4}^{-}\right)$ & 2.349 & & 2.779 & & 2.654 & & \\
\hline & & & 148.7 & & 155.8 & & 134.3 & & 60 \\
\hline \multirow[t]{2}{*}{$\mathrm{H}$} & $\mathrm{Me}$ & $\mathrm{F}\left(\mathrm{PF}_{6}^{-}\right)$ & 2.559 & & 2.690 & & 2.644 & & \\
\hline & & & 128.8 & & 132.8 & & 119.2 & & 35 \\
\hline \multirow[t]{2}{*}{$\mathrm{Me}$} & ${ }^{n}$ Dod. & $\mathrm{F}\left(\mathrm{PF}_{6}^{-}\right)$ & 2.578 & 2.504 & 2.587 & 2.402 & 2.592 & 2.699 & \\
\hline & & & 103.1 & 163.4 & 139.8 & 164.9 & 114.4 & 138.7 & 36 \\
\hline \multirow[t]{2}{*}{$\mathrm{PhMe}$} & $\mathrm{PhMe}$ & $\mathrm{Cl}\left(\mathrm{Cl}^{-}\right)$ & 2.546 & 2.698 & 2.899 & 2.556 & & & \\
\hline & & & 161.7 & 164.3 & 143.7 & 165.8 & & & 37 \\
\hline \multirow[t]{2}{*}{$\mathrm{PhMe}$} & $\mathrm{Ph}, \mathrm{Me}$ & $\mathrm{F}\left(\mathrm{BF}_{4}^{-}\right)$ & 2.267 & 2.548 & 2.561 & 2.514 & 2.613 & & \\
\hline & & & 146.1 & 128.6 & 115.9 & 137.5 & 134.2 & & 55 \\
\hline \multirow[t]{2}{*}{$\mathrm{PhMe}$} & $\mathrm{PhMe}$ & $\mathrm{F}\left(\mathrm{PF}_{6}^{-}\right)$ & 2.203 & 2.525 & 2.536 & & & & \\
\hline & & & 153.5 & 151.0 & 124.3 & & & & 55 \\
\hline
\end{tabular}

${ }^{a}$ The sum of van der Waals radii for $\mathrm{H} / \mathrm{F} ; \mathrm{H} / \mathrm{Cl} ; \mathrm{H} / \mathrm{Br}$ and $\mathrm{H} / \mathrm{I}$ are: $2.67 ; 3.09 ; 3.48$ and $3.86 \AA$, respectively; ${ }^{\mathrm{b}} \mathrm{C}-\mathrm{X}$ bond distance. 

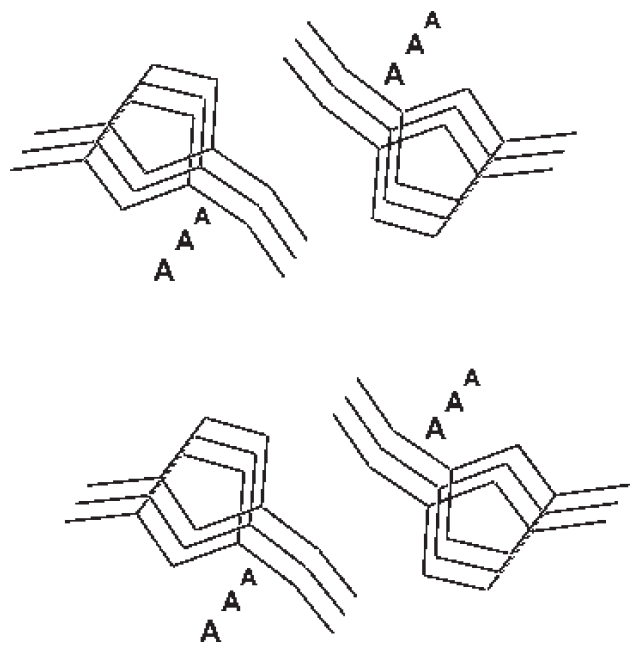

Figure 3. A schematic view of the arrangements of imidazolium cations showing the channels in which the spherical anions (A) are accommodated.

is: $\left.\left.\left[(\mathrm{DAI})_{\mathrm{x}}(\mathrm{X})_{\mathrm{x}-\mathrm{n}}\right)\right]^{\mathrm{n}+}\left[(\mathrm{DAI})_{\mathrm{x}-\mathrm{n}}(\mathrm{X})_{\mathrm{x}}\right)\right]^{\mathrm{n}-}$. where DAI is the $1,3-$ dialkylimidazolium cation and $\mathrm{X}$ is the anion.

\section{Structural Organization in Liquid and Gas Phase}

Is this structural feature maintained in the liquid phase? Several indications indicate that indeed 1,3dialkylimidazolium possess analogous structural patterns in both the solid and liquid phase and to some extent even in the gas phase. Note that although significant randomness in organization is necessary to describe the structure of a liquid, in most of the cases there is only $10-15 \%$ volume expansion on going from the crystalline to the liquid state and the ion-ion or atom-atom distances are similar in both, the solid in liquid states. Furthermore, while long-range order is lost on going from the crystal to the liquid, similarities remain as a consequence of the Coulombic forces between cations and anions of the imidazolium ionic liquids. ${ }^{38}$ It is clear that the long-range Coulomb interactions in ionic organic liquids can lead to longer spatial correlations than those in comparable van der Waals organic liquids. ${ }^{39}$

The IR spectra of these materials in both the solid and liquid phase are almost identical and show the characteristic $\mathrm{C}-\mathrm{H} \cdots \mathrm{X}$ hydrogen bonding bands ${ }^{40}$ in the region $3100-3200 \mathrm{~cm}^{-1}$ pertaining to the interaction of $\mathrm{H} 2$, $\mathrm{H} 4 \mathrm{H} 5$ of the imidazolium cations with the anions (Figure 4).

The hydrogen bonding system between the cation and anion has been also evidenced by NMR studies of pure liquid organo-aluminate imidazolium molten salts. The

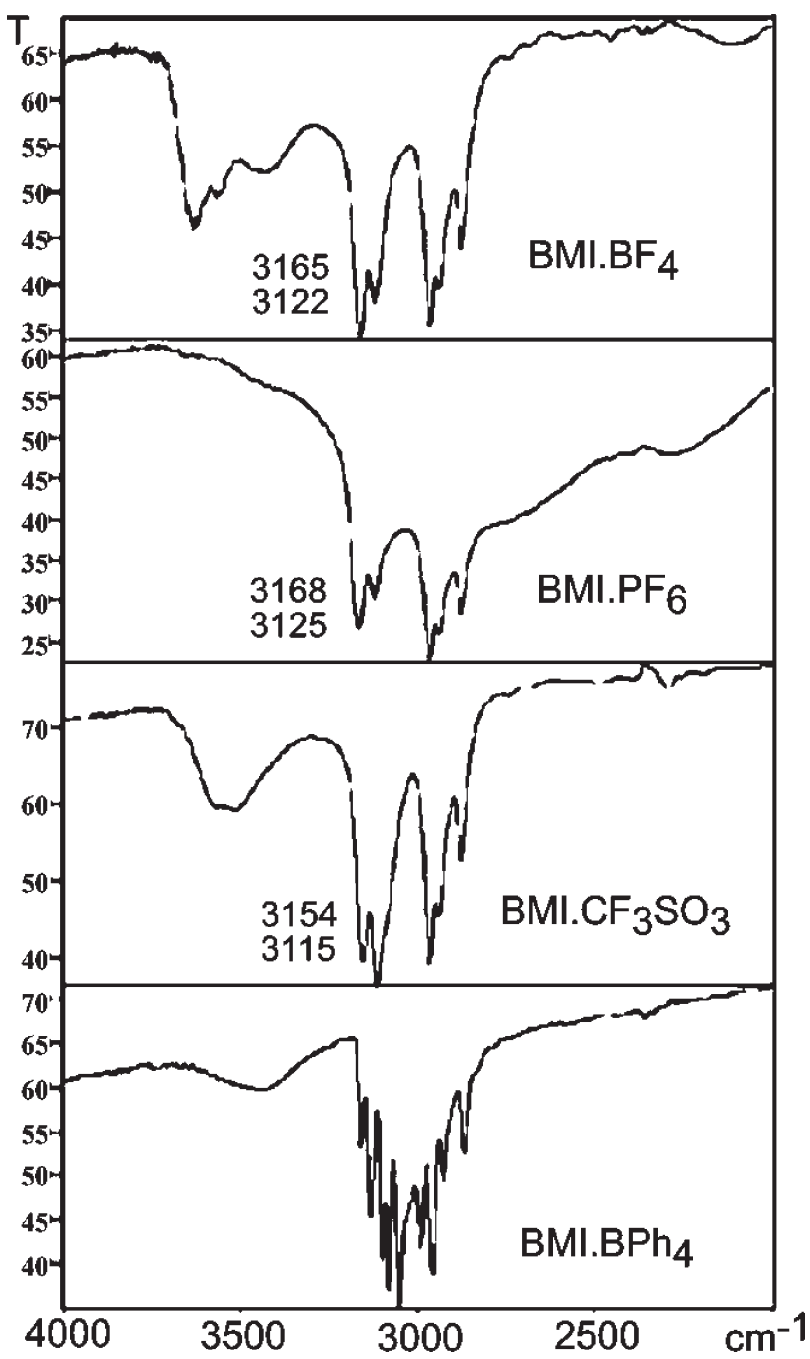

Figure 4. Infrared spectra of some 1-n-butyl-3-methylimidazolium ionic liquids showing the C-H...F stretching frequencies (3100$3200 \mathrm{~cm}^{-1}$ ).

imidazolium $\mathrm{H}$ chemical shifts change with the concentration of $\mathrm{AlCl}_{3}$ (Lewis acidity of the liquid). ${ }^{41}$ Moreover, $\mathrm{H}, \mathrm{H}-\mathrm{NOESY}$ experiments indicate the existence of spin diffusion in 1,3-dialkyimidazolium ionic liquids. ${ }^{42}$

Recoil Spectrometry experiments with liquid BMI.PF indicated that bulk stoichiometry is conserved at the surfaces (the surface is neither enriched with the cation nor with the anion). The $\mathrm{N}$-imidazolium atoms and alkyl side chains are deeper in the surface and the average orientation of the cation is with the plane of the ring in the vertical position. ${ }^{43}$

However, one of the strongest evidences has been recently obtained through the structural investigation of 1,3-dimethylimidazoliumchloride (DMI.Cl) and its hexafluorophosphate analogue (DMI.PF $\left.{ }_{6}\right)$ by neutron diffraction analysis in both the solid and liquid phase. 
The model derived from the obtained data using Empirical Potential Structure Refinement indicated that significant charge ordering is present in the liquid phase and that the local order in these liquids resembles those found in the solid phase. ${ }^{44}$ Similar observations have been obtained from various $\mathrm{X}$-ray and neutron scattering studies of solid and liquid $\mathrm{NaCl}$, i.e, the structural organization observed in the crystal exists in the liquid phase. ${ }^{45}$

Moreover, the Raman spectra ${ }^{46}$ of crystalline and liquid state of BMI.Cl are quite similar indicating the threedimensional structure found in the solid state ${ }^{32}$ is maintained in the liquid phase. Optical heterodynedetected optical Kerr effect (OHD-OKE) experiments used to study the orientational dynamics of 1-ethyl-3methylimidazolium nitrate indicated that the nature of the interactions in this ionic liquid is very different to those occurring in van der Waals organic liquids. These intermolecular interactions are stronger than those in the van der Waals liquids and in liquid crystals. ${ }^{38}$

This structural pattern is even maintained in the gas phase and evidence for the clustering - supramolecules formed through association of the 1,3-dialkylimidazolium cation with the anions - has been obtained by mass spectrometry experiments. Clusters of the type $\left[(\mathrm{DAI})_{2}\left(\mathrm{AlCl}_{4}\right)\right]^{+}(\mathrm{DAI}=1,3$-dialkylimidazolium cation $)$ have been observed in organo-aluminate molten salts under conditions of fast atom bombardment mass spectrometry (FAB-MS) ${ }^{47}$ Moreover, electron spray mass spectrometry experiments in both positive and negative modes (ESI $(+)$ and ESI(-)) of various 1,3-dialkylimidazolium cations associated with different anions show also the formation of supramolecular structures of the type $\left.\left[(\mathrm{DAI})_{\mathrm{x}}(\mathrm{X})_{\mathrm{x}-\mathrm{n}}\right)\right]^{\mathrm{n}+}$ $\left.\left[(\mathrm{DAI})_{\mathrm{x}-\mathrm{n}}(\mathrm{X})_{\mathrm{x}}\right)\right]^{\mathrm{n}-}(\mathrm{x}, \mathrm{n}=1,2,3, \ldots$ and $\mathrm{x}>\mathrm{n})$. In the case of $\mathrm{BMI} \mathrm{BF}_{4}$ (dissolved in acetonitrile and then transferred to the gas phase) the series of a single-charged supramolecules $(\mathrm{n}=1)$ with $\mathrm{x}$ varying form 1 to 13 (Figure 5). Notably, double-charged ( $n=2$ and $x$ varying from 13 to 25$)$ and triple charged clusters ( $n=3$ and varying from 34 to 39 ) are also detected..$^{48}$ Notably, stable supramolecular aggregates with magic masse numbers such as $\left[(\mathrm{DAI})_{2}\left(\mathrm{BF}_{4}\right)_{3}\right]^{-}$and $\left[(\mathrm{DAI})_{5}\left(\mathrm{BF}_{4}\right)_{4}\right]^{+}$were found in the case of the tetrafluoroborate anion.

More interestingly, it was possible to produce and isolate mixed clusters of the type $\left[\left(\mathrm{X}^{1}\right) \mathrm{BMI}\left(\mathrm{X}^{2}\right)\right]^{-}\left(\mathrm{X}^{1}, \mathrm{X}^{2}=\right.$ $\mathrm{CF}_{3} \mathrm{SO}_{3}, \mathrm{PF}_{6}, \mathrm{BF}_{4}$ and $\mathrm{BPh}_{4}$ ) via mass-selection and then dissociate by collision activation to determine the intrinsic strength of the hydrogen bonds between imidazolium cation and anions. The strength of the hydrogen bonds follows the order $\mathrm{CF}_{3} \mathrm{CO}_{2}>\mathrm{BF}_{4}>\mathrm{PF}_{6}>\mathrm{BPh}_{4}^{-}$, which is in the same order as those obtained earlier based on IR studies. $^{3}$

\section{Structural Organization in Solution}

It is evident that "pure" 1,3-dialkyimidazolium ionic liquids in the solid, liquid and gas phase are well-organized hydrogen-bonded polymeric supramolecules. Moreover there is now much evidence indicating that some of the supramolecular organization can be maintained when they are mixed with other substances. 1,3-Dialkylimidazolium ionic liquids-aromatic mixtures form liquid clathrates and

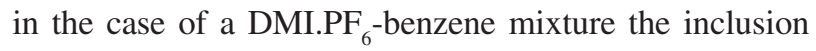
compound [(DMI.PF $)_{2}$ (benzene $\left.)\right]_{n}$ could be trapped and its $\mathrm{X}$-ray structure determined. ${ }^{49}$ This compound maintains a three-dimensional hydrogen bonded network of anions and cations with the formation of channels in which the benzene molecules are included. The benzene molecules are isolated within the channels and they are staggered through $\pi-\pi$

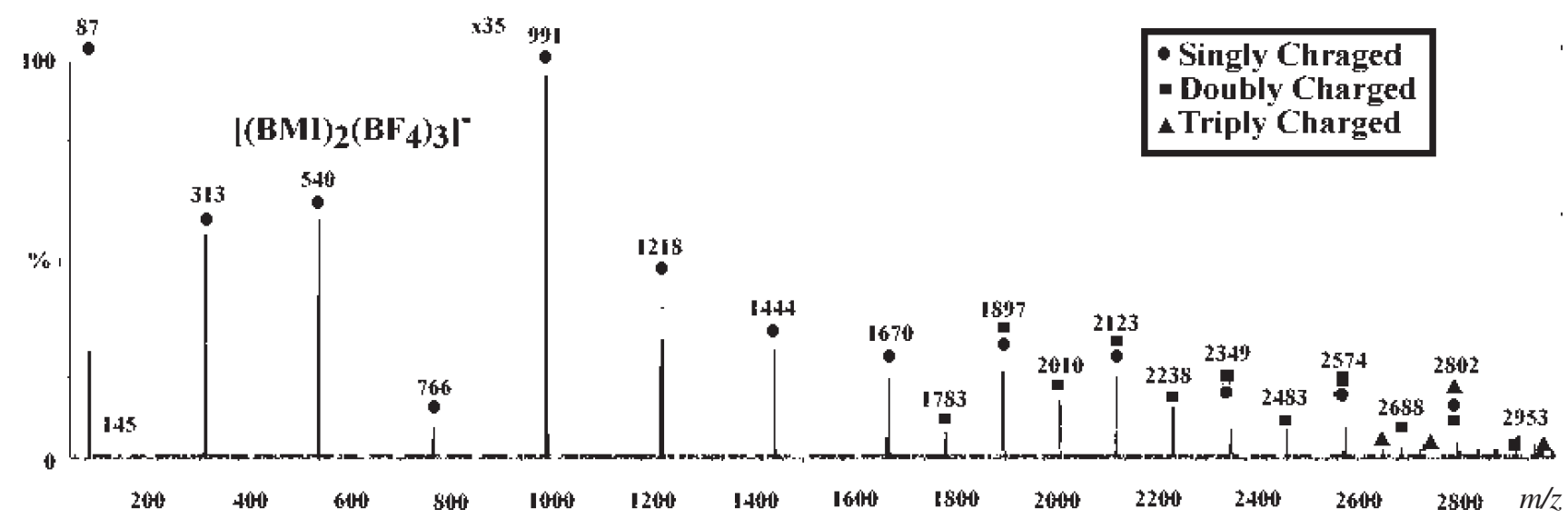

Figure 5. ESI-(-) mass spectrum of $\mathrm{BMI}_{\mathrm{BF}}{ }_{4}$ from an acetonitrile solution. Note the series of singly negatively charged gaseous $\left[(\mathrm{BMI})_{\mathrm{n}}(\mathrm{BF} 4)_{\mathrm{n}+1}\right]^{-}$ supramolecules of $\mathrm{m} / \mathrm{z} 313,540,766,991$, and so on $\left(\Delta \mathrm{m} / \mathrm{z}, 226\right.$ for $\left.{ }^{10} \mathrm{~B}\right)$. The spectrum has been blown up from $\mathrm{m} / z$, 900 to show more clearly the series of doubly charged supramolecules $\left[(\mathrm{BMI})_{\mathrm{n}}\left(\mathrm{BF}_{4}\right)_{\mathrm{n}+2}\right]^{-2}(\mathrm{n}=13-25)$ of $\mathrm{m} / \mathrm{z} 1556,1670,1783$, and so on $\left(\Delta m / z\right.$, 113 for $\left.{ }^{10} \mathrm{~B}\right)$, and the triply charged ones $\left[(\mathrm{BMI})_{\mathrm{n}}(\mathrm{BF} 4)_{\mathrm{n}+3}\right]^{-3}(\mathrm{n}=34-39)$ of $\mathrm{m} / \mathrm{z} 2648,2723,2799,2802$ and so on $\left(\Delta m / z 75.3\right.$ for $\left.{ }^{10} \mathrm{~B}\right)$. 
sandwich between two imidazolium cations. It is worth to note that again one cation is surrounded by three anions and in its turn each anion is surrounded by three cations. It is interesting to note that inclusion of benzene molecules in the ILs is a relative slow process. The solubility of benzene in BMI.PF ${ }_{6}$ is 0.66 -mole fraction ${ }^{50}$ but this value is attained only after around 45 minutes of mixing. If the mixture was left to mix for less time, such as $15 \mathrm{~min}$, a solubility of around 20 -wt $\%$ was observed. ${ }^{51}$

The solvatation of the 1,3-dialkylimidazolium ionic liquids follows the same trend observed for classical quaternary ammonium salts ${ }^{52}$ i.e. it occurs only with anions, ${ }^{53}$ at least for saturated molecules. ${ }^{54}$ The conductivity of 1,3-dialkylimidazolium liquids such as $\mathrm{BMI} \mathrm{BF}_{4}, \mathrm{BMI} \mathrm{PF}_{6}$ and $\mathrm{BMI} \mathrm{BPh}_{4}$ dissolved in organic solvents behaves like classical quaternary ammonium salts. ${ }^{55}$ The conductivity initially decreases with an increase in concentration and then increases with a further increase in salt concentration (Figure 6) $)^{55,56}$ indicating the formation of triple ions of the type $\left[(\mathrm{DAI})_{2}(\mathrm{X})\right]^{+}\left[(\mathrm{DAI})(\mathrm{X})_{2}\right]^{-}$.

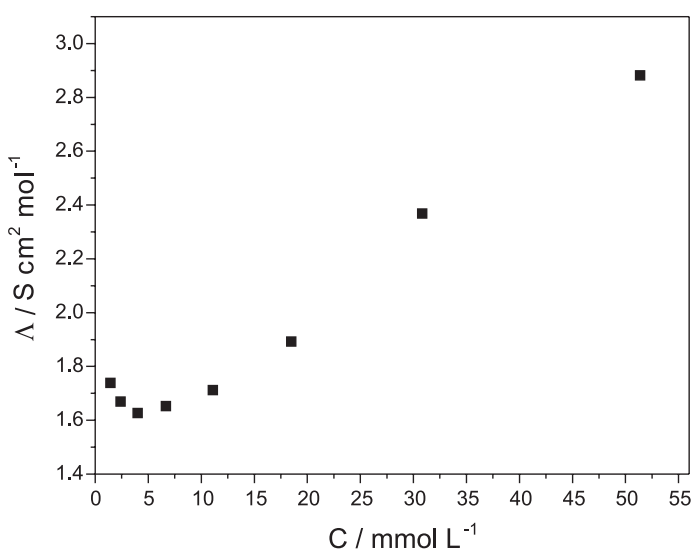

Figure 6. Variation of the conductivity with the concentration of BMI.PF ${ }_{6}$ in 8 wt\% of $\mathrm{CH}_{3} \mathrm{CN}$ in $\mathrm{CHCl}_{3}$.

The formation of hydrogen-bonded aggregates through disruption of the polymeric structure can also explain the augmentation of the BMI.PF 6 conductivity when saturated with carbon dioxide (a molecule with a relatively large quadrupole moment). Indeed, an increment of greater than 3 times (from $3 \times 10^{3}$ to $10 \times 10^{3} \mathrm{Scm}^{-1}$ ) in the conductivity was observed by the addition of 60 bar of $\mathrm{CO}_{2}$ at $50{ }^{\circ} \mathrm{C} .{ }^{57}$ Indeed, an irregular ionic lattice model has been successful used to predict the $\mathrm{CO}_{2}$ solubilities with $\mathrm{BMI} \mathrm{PF}_{6}{ }^{58}$

The formation of such floating aggregates was also observed by analyzing the changes of solution enthalpies of these ILs in chloroform. ${ }^{55}$ For example, at very low concentrations a constant value for the enthalpy of solution is observed. As the concentration increases the enthalpy starts to change (to at around $60 \mathrm{mmol} \mathrm{L}^{-1}$ ) and further increasing the $\mathrm{BMI} \mathrm{BF}_{4}$ concentration another deviation at concentrations around $110 \mathrm{mmol} \mathrm{L}^{-1}$ is observed with a reverse enthalpy variation (Figure 7). These enthalpy variations can be associated with the formation of contact ion pairs followed by their association forming triple ions.

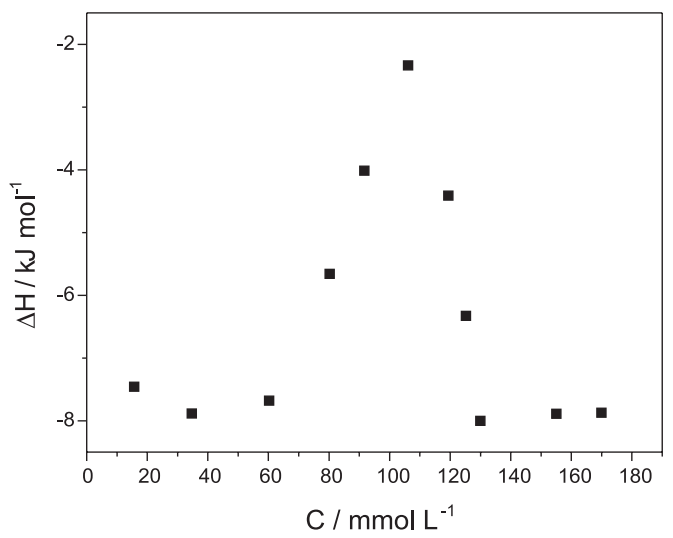

Figure 7. $\Delta_{\text {sol }} \mathrm{H}$ changes of $\mathrm{BMI}_{\mathrm{B}} \mathrm{BF}_{4}$ in chloroform with the salt concentration.

Multinuclear NMR studies with EMI.X $(\mathrm{X}=\mathrm{Cl}, \mathrm{Br}$ and I) ionic liquids indicated that they form contact ion pairs (through hydrogen bonds of the imidazolium hydrogens with the halide anions) even in relatively polar molecular solvents such as propionitrile. In trichloro and dichloromethane these salts exits in quasi-molecular states showing the classical aromatic (imidazolium) stacking

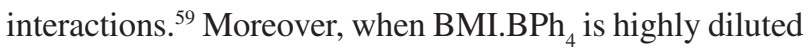
in solvents of high dielectric constant such is DMSO they form solvent separated ion pairs. In opposition when dissolved in solvents of relatively low dielectric constants such as $\mathrm{CDCl}_{3}$ they form contact ion pairs (via $\mathrm{C}-\mathrm{H}^{\cdots} \cdots \pi$ bonds) as observed by ${ }^{1} \mathrm{H}$ NOESY NMR experiments with $\mathrm{BMI}^{\mathrm{BPh}}{ }_{4}{ }^{60}$ The apparent volumes for the cation and anion, calculated from ${ }^{13} \mathrm{C}-\mathrm{NMR}$ relaxation times, increases with an increase in the concentration indicating the formation of floating aggregates through hydrogen bonds. Similar results have been obtained by NMR studies with 1-ethyl-3-methylimidazolium tetrafluoroborate ionic liquid. ${ }^{61}$ More recently, it has also been demonstrated by heteronuclear NMR experiments on $\mathrm{BMI}_{\mathrm{BF}} \mathrm{BF}_{4}$ that contact ion pairs exist in the presence of small amounts of water and even in DMSO solution. ${ }^{62}$

It is very clear that in the 1,3-dialkylimidazolium ionic liquids maintain to a great extent their hydrogen-bonded network of the type $\left.\left.\left[(D A I)_{x}(X)_{x-n}\right)\right]^{n+}\left[(D A I)_{x-n}(X)_{x}\right)\right]^{n-}$ in the presence of other molecules and macromolecules. Therefore the incorporation of molecules and macromolecules in the ionic liquid network causes changes to the physicalchemical properties of these materials and can cause, in some cases, the formation of polar and non-polar regions. 
Compton was the first to propose that mixtures of imidazolium ionic liquids with other molecules should be described as nano-structured materials while investigating the diffusion coefficient of neutral and charged molecules in these liquids containing controlled amounts of water. ${ }^{63}$ Thus, the diffusion coefficients for two representative redox systems, the oxidation of neutral N,N,N',N'-tetramethyl- $p$ phenylenediamine (TMPD), the reduction of cationic methyl viologen $\left(\mathrm{MV}^{2+}\right)$, have been determined as a function of the water content of the ionic liquids (BMI.BF 4 and BMI.PF ${ }_{6}$ ). Clearly, very different effects of water on the rate of diffusion of ionic and neutral species in ionic liquids (Table 3) are observed and the conventional correlation of rate of diffusion and viscosity (Stokes-Einstein) fails.

This behavior can be attributable to the presence of a nano-structure in the wet ionic liquid, which allows neutral molecules to reside in less polar regions and ionic species to undergo faster diffusion in the more polar or wet regions. This type of nano-inhomogeneity is also encountered in some liquid crystalline or concentrated surfactant media. ${ }^{64}$

Table 3. Diffusion coefficient data $\left(\mathrm{D} / \mathrm{cm}^{2} \mathrm{~s}^{-1}\right)$ determined from the limiting current for the oxidation process (TMPD) and reduction (MV2+) processes

\begin{tabular}{|c|c|c|c|c|}
\hline \multirow[t]{2}{*}{ IL } & \multicolumn{2}{|l|}{ TMPD } & \multicolumn{2}{|l|}{$\mathrm{MV}^{2+}$} \\
\hline & Dry & Wet $^{\text {a) }}$ & Dry & Wet $^{\mathrm{a})}$ \\
\hline $\mathrm{BMI} \mathrm{BF}_{4}$ & n.d. & n.d. & $1.5 \times 10^{-8}$ & $2.7 \times 10^{-7}$ \\
\hline BMI.PF $_{6}$ & $2.6 \times 10^{-8}$ & $5.2 \times 10^{-8}$ & $1.1 \times 10^{-8}$ & $1.0 \times 10^{-7}$ \\
\hline
\end{tabular}

a 25 wt.\% in BMI.BF ${ }_{4}$ and 5-6 wt.\% in BMI.PF 6 . n.d. $=$ not determined.

The effect of water on the diffusion coefficient for neutral and for ionic species suggests that wet ionic liquids may not be regarded as homogeneous solvents, but have to be considered as nano-structures with polar and nonpolar regions. The presence of these hydrogen-bonded nano-structures with polar and non-polar regions may be responsible for the stabilization of enzymes supported in ionic liquids that can maintain their functionality under very extreme denaturative conditions. It is well known that the thermal stability of enzymes is enhanced in both aqueous and anhydrous media containing polyols as a consequence of the increase in hydrogen bond interactions. Thus, both the solvophobic interactions essential to maintain the native structure and the water shell around the protein molecule are preserved by the "inclusion" of the aqueous solution of free enzyme into the IL network, resulting in a clear enhancement of the enzyme stability. In the case of immobilized enzyme (Novozym 435), no loss of activity has been observed at $120{ }^{\circ} \mathrm{C}$ and the resulting half-life time at $150{ }^{\circ} \mathrm{C}$ was twice that observed for the free enzyme. In this case, the enzyme-support interactions combined with the influence of IL improving greatly the enzyme stability. ${ }^{11}$

The presence of these nano-inhomogeneities with polar and non-polar regions provides highly interesting properties for the application of ionic liquids in separation processes and as media for the generation of nano-materials. Imidazolium ionic liquids when used as stationary phases for gas chromatography seem to have a dual nature. For example they act as a low-polarity stationary phase to nonpolar compounds whereas molecules with strong proton donor groups are tenaciously retained. ${ }^{9}$

Transition-metal nanoparticles can be generated by simple reduction of metal salts or by controlled decomposition of organometallic compounds "dissolved" in imidazolium ionic liquids. Using this approach various stable nanometric transition-metal particles with narrow size and size distribution can be prepared. Moreover, since most of imidazolium ionic do not possess a measurable vapor pressure the $\mathrm{Pt}(0)$ nanoparticles imbibed in ${\mathrm{BMI} . \mathrm{PF}_{6}}_{6}$ ionic liquid could be examined by Transmission Electron Microscopy (TEM). A detailed examination of the nanoparticles imbibed in the ionic liquid and their environment shows an interaction of the BMI.PF ${ }_{6}$ ionic liquid with the $\operatorname{Pt}(0)$ nanoparticles (Figure 8). ${ }^{65}$

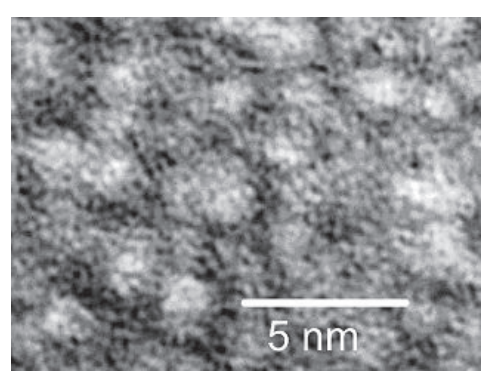

Figure 8. TEM micrograph (negative image - under-focus) of the

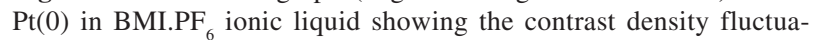
tion around the metal nanoparticles.

The interaction between transition-metal nanoparticles with the ionic liquid can be described as nano-particle inclusion compound. Not surprisingly, imidazolium ionic liquids easily form micro-emulsions using different surfactants such as long chain alcohols and the properties of the new micelle-ionic liquid solutions can be explored in inverse gas chromatography processes. ${ }^{66}$ Moreover, nano-structured materials can be constructed within these ionic liquid-micro emulsions. ${ }^{67}$

\section{Conclusions}

In summary pure 1,3-dialkylimidazolium ionic liquids are hydrogen-bonded polymeric supramolecules of the 
type $\left.\left.\left[(\mathrm{DAI})_{\mathrm{x}}(\mathrm{X})_{\mathrm{x}-\mathrm{n}}\right)\right]^{\mathrm{n}+}\left[(\mathrm{DAI})_{\mathrm{x}-\mathrm{n}}(\mathrm{X})_{\mathrm{x}}\right)\right]^{\mathrm{n}-}$ where DAI is the $1,3-$ dialkylimidazolium cation and $\mathrm{X}$ is the anion. This structural pattern is a general trend for both, the solid and the liquid phase and is apparently maintained to a great extent even in the gas phase. The introduction of other molecules and macromolecules occurs with a disruption of the hydrogen bond network and in some cases generating nano-structures with polar and non-polar regions where inclusion-type compounds can be formed. These inclusion compounds can involve molecules (such as arenes) ${ }^{49}$ ions (such as charged transition-metal complexes) ${ }^{68}$, macromolecules (such as enzymes ${ }^{11}$ or cellose ${ }^{69}$ ) and nanoparticles (such as transition-metal nano clusters) ${ }^{15}$ and the stabilization of this process is mainly due to the electronic and steric effects provided by the nano-structures of the type $\left.\left.\left[(\mathrm{DAI})_{\mathrm{x}}(\mathrm{X})_{\mathrm{x}-\mathrm{n}}\right)\right]^{\mathrm{n}+}\left[(\mathrm{DAI})_{\mathrm{x}-\mathrm{n}}(\mathrm{X})_{\mathrm{x}}\right)\right]^{\mathrm{n}-}$. When they are infinitely diluted in other molecules they can form solventseparated ion pairs that an increase of the concentration of the imidazolium salt they collapse to form contact ion pairs - through hydrogen bonds involving the cation with the anion - and a further salt concentration increment leads to triple ions, etc, (Figure 9).

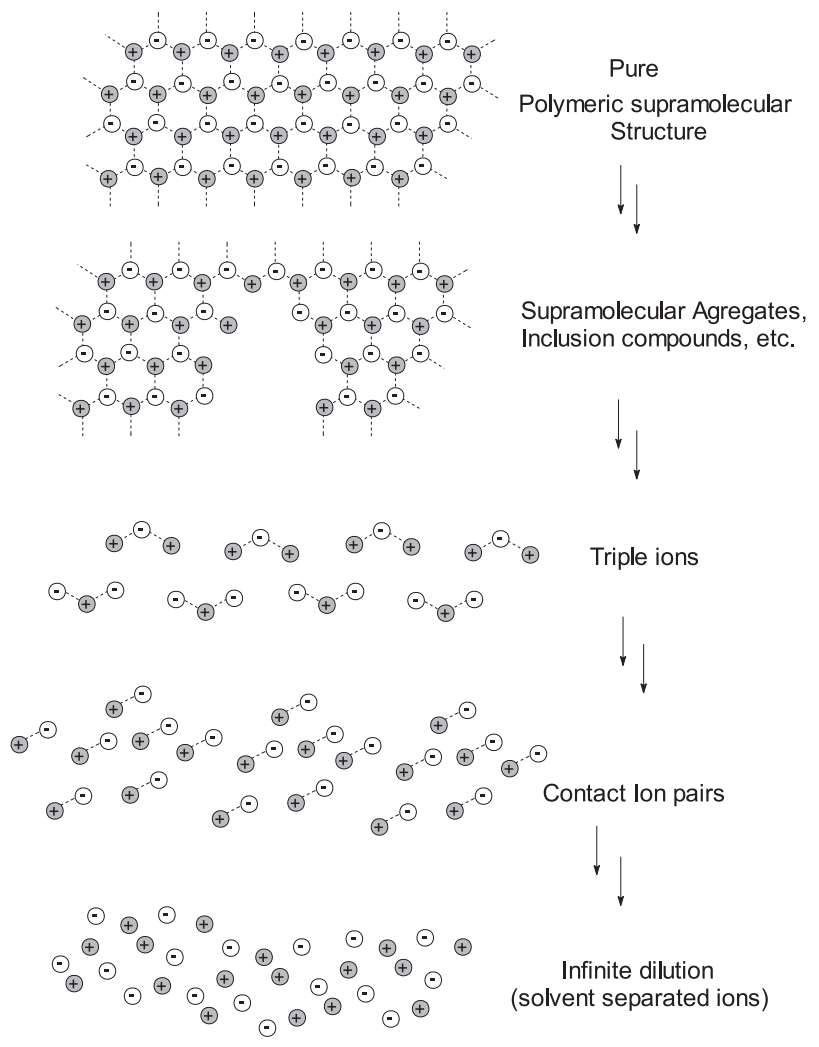

Figure 9. Simplified two-dimensional model of the structural features of 1,3-dialkylimidazolium ionic liquids from hydrogen-bonded polymeric supramolecules (pure form) to solvent separated ion pairs (infinite dilution). + Represents the 1,3-dialkylimidazolium cation, - the anion and the dashed line the hydrogen bonds.

\section{Acknowledgments}

Thanks are due to CNPq, FAPERGS, CTPETRO, CAPES and CENPES-Petrobras for financial support for the ionic liquid project since 1992. I am also in debt with all my coworkers whose names appear in the references for cooperation on the ionic liquid project.

\section{References}

1. Chauvin, Y.; Mussmann, L.; Olivier, H.; Angew.Chem.Int.Ed.Engl. 1996, 34, 2698 ; Suarez, P. A. Z.; Dullius, J. E. L.; Einloft, S.; deSouza, R. F.; Dupont, J.; Polyhedron 1996, 15, 1217; Bonhote, P.; Dias, A. P.; Papageorgiou, N.; Kalyanasundaram, K.; Gratzel, M. Inorg.Chem. 1996, 35, 1168.

2. One of the first 1,3-dialkylimidazolium room temperature ionic liquid (RTIL) - obtained through the mixing of 1-ethyl3-methylimidzolium chloride with aluminum trichloride - was reported more that a half of century ago. Hurley, F. H.; Wier, T. P.; J. Electrochem. Soc. 1951, 98, 203. However, these organo-aluminate ionic liquids are unstable to air, water and they are not inert towards various organic compounds, which has most probably limited their range of applications.

3. Suarez, P. A. Z.; Einloft, S.; Dullius, J. E. L.; de Souza, R. F.; Dupont, J.; J. Chim. Phys. Phys. -Chim. Biol. 1998, 95, 1626.

4. Dupont, J.; Suarez, P. A. Z.; Consorti, C. S.; de Souza, R. F.; Org. Synth. 2002, 79, 236.

5. See for examples: Baudequin, C.; Baudoux, J.; Levillain, J.; Cahard, D.; Gaumont, A.-C.; Plaquevent, J.-C.; Tetrahedron Asymm. 2003, 14, 3081; Song, C. E.; Chem. Commun. 2004, 1033; Dupont, J.; de Souza, R. F.; Suarez, P. A. Z.; Chem. Rev. 2002, 102, 3667; Olivier-Bourbigou, H.; Magna, L.; J. Mol. Catal. A-Chem. 2002, 182, 419; Dyson, P. J.; Trans. Metal Chem. 2002, 27, 353; Gordon, C. M.; Appl. Catal. A-Gen. 2001, 222, 101; Sheldon, R.; Chem. Commun. 2001, 2399; Wasserscheid, P.; Keim, W.; Angew. Chem. Int. Ed. 2000, 39, 3773; Dupont, J.; Consorti, C. S.; Spencer, J.; J. Braz. Chem. Soc. 2000, 11, 337; Welton, T.; Chem. Rev. 1999, 99 2071; Seddon, K. R.; J. Chem. Technol. Biotechnol. 1997, 68, 351; Chauvin, Y.; Act. Chim. 1996, 44.

6. de Souza, R. F.; Padilha, J. C.; Gonçalves, R. S.; Dupont, J.; Electrochem. Comm. 2003, 5, 728.

7. Wang, P.; Zakeeruddin, S. M.; Comte, P.; Exnar, I.; Gratzel, M.; J . Am. Chem. Soc. 2003, 125, 1166.

8. Reich, R. A.; Stewart, P. A.; Bohaychick, J.; Urbanski, J. A.; Lub. Eng. 2003, 59, 16; Ye, C. F.; Liu, W. M.; Chen, Y. X.; Yu, L. G.; Chem. Commun. 2001, 2244.

9. Anderson, J. L.; Armstrong, D. W.; Anal. Chem. 2003, 75, 4851; Armstrong, D. W.; He, L. F.; Liu, Y. S.; Anal. Chem. 1999, 71,3873 . 
10. Armstrong, D. W.; Zhang, L-K.; He, L.; Gross, M. L.; Anal. Chem. 2001, 73, 3679-3686; Dyson, P. J.; McIndoe, J. S.; Zhao, D. B.; Chem. Commun. 2003, 508; Carda-Broch, S.; Berthod, A.; Armstrong, D. W.; Rapid Commun. Mass Spectrom. 2003, 17, 553.

11. See for example: Park, S.; Kazlauskas, R.; Curr. Opin. Biotech. 2003, 14, 432; Lozano, P.; de Diego, T.; Carrie, D.; Vaultier, M.; Iborra, J. L.; Biotech. Prog. 2003, 19, 380.

12. Abraham, M. H.; Zissimos, A. M.; Huddleston, J. G.; Willauer, H. D.; Rogers, R. D.; Acree, W. E; .Ind. Eng. Chem. Res. 2003, 42, 413; Branco, L. C.; Crespo, J. G.; Afonso, C. A. M.; Angew. Chem. Int. Ed. 2002, 41, 2771; Branco, L. C.; Crespo, J. G.; Afonso, C. A. M.; Chem. Eur. J. 2002, 8, 3865.

13. Holbrey, J. D.; Seddon, K. R.; J. Chem. Soc. Dalton Trans. 1999, 2133.

14. Adams, C. J.; Bradley, A. E.; Seddon, K. R.; Aust. J. Chem. 2001, 54, 679.

15. Dupont, J.; Fonseca, G. S.; Umpierre, A. P.; Fichtner, P. F. P.; Teixeira, S. R.; J. Am. Chem. Soc. 2002, 124, 4228; Fonseca, G. S.; Umpierre, A. P.; Fichtner, P. F. P.; Teixeira, S. R.; Dupont, J.; Chem. Eur. J. 2003, 9, 3263; Huang, J.; Jiang, T.; Han, B. X.; Gao, H. X.; Chang, Y. H.; Zhao, G. Y.; Wu, W. Z.; Chem.Commun. 2003, 1654.

16. Carmichael, A. J.; Hardacre, C.; Holbrey, J. D.; Nieuwenhuyzen, M.; Seddon, K. R.; Mol. Phys. 2001, 99, 795.

17. Majewski, P.; Pernak, A.; Grzymislawski, M.; Iwanik, K.; Pernak, J.; Acta Histochemica 2003, 105, 135.

18. Wasserscheid, P. Welton, T., eds.; Ionic Liquids in Synthesis, Wiley-VCH: New York, 2002; Rogers, R. D.; Seddon, K. R.; Ionic Liquids Industrial Applications to Green Chemistry 2001, ACS, Symposium Series 818.

19. See for examples: Paulechka, Y. U.; Kabo, G. J.; Blokhin, A. V.; Vydrov, O. A.; Magee, J. W.; Frenkel, M.; J. Chem. Eng. Data 2003, 48, 457; de Andrade, J.; Boes, E. S.; Stassen, H.; J. Phys. Chem. B 2002, 106, 3546; Headley, A. D.; Jackson, N. M.; J. Phys. Org. Chem. 2002, 15, 52; Shah, J. K.; Brennecke, J. F.; Maginn, E. J.; Green. Chem. 2002, 4, 112; Koch, V. R.; Dominey, L. A.; Nanjundiah, C.; Ondrechen, M. J.; J. Electrochem. Soc. 1996, 143, 798; Takahashi, S.; Curtiss, L. A.; Gosztola, D.; Koura, N.; Saboungi, M. L.; Inorg.Chem. 1995, 34, 2990.

20. Nishida, T.; Tashiro, Y.; Yamamoto, M.; J. Fluorine Chem. 2003, 120, 135 .

21. Huddleston, J. G.; Visser, A E.; Reichert, W. M.; Willauer, H. D.; Broker, G. A.; Rogers, R. D.; Green Chem. 2001, 3, 156.

22. Fannin Jr., A. A.; Floreani, D. A.; King, L. A.; Landers, J. S.; Piersma, B. J.; Stech, D. J.; Vaughn, R. L.; Wilkes, J. S.; Williams, J. L.; J. Phys. Chem. 1984, 88, 2614.

23. Dyson, P. J.; Laurenczy, G.; Ohlin, C. A.; Vallance, J.; Welton, T.; Chem. Commun. 2003, 2418.

24. Merck Index, 12, 3844.
25. Siegel, R. W.; Nanophase Materials, Encyclopedia of Applied Physics, VCH Publishers: Weinheim, 1994, vol. 11, p. 173.

26. Data obtained from Cambridge Crystallographic Data Center (www. ccdc.can.ac.uk.).

27. Amyes, T. L.; Diver, S. T.; Richard, J. P.; Rivas, F. M.; Toth, K.; J. Am. Chem. Soc. 2004, in press.

28. For a detailed discussion concerning the different types of hydrogen bonds see: Jeffrey, G. A.; An Introduction to Hydrogen Bonding, Oxford University Press: Oxford, 1997.

29. van den Broeke, J.; Stam, M.; Lutz, M.; Kooijman, H.; Spek, A. L.; Deelman, B. J.; van Koten, G.; Eur .J .Inorg. Chem. 2003, 2798.

30. Dymek Jr., C. J.; Grossie, D. A.; Fratini, A. V.; Adams, W. W.; J. Molec. Struct. 1989, 213, 25.

31. Holbrey, J. D.; Reichert, W. M.; Nieuwenhuyzen, M.; Johnston, S.; Seddon, K. R.; Rogers, R. D.; Chem. Commun. 2003, 1636.

32. Saha, S.; Hayashi, S.; Kobayashi, A.; Hamaguchi, H.; Chem. Lett. 2003, 32, 740.

33. Swatloski, R. P.; Holbrey, J. D.; Rogers, R. D.; Green. Chem. 2003, 5, 361.

34. Elaiwi, A.; Hitchcock, P. B.; Seddon, K. R.; Srinivasan, N.; Tan, Y. M.; Welton, T.; Zora, J. A.; J. Chem. Soc. Dalton Trans. 1995, 3467.

35. Fuller, J.; Carlin, R. T.; Delong, H. C.; Haworth, D.; J. Chem. Soc. Chem. Commun. 1994, 299.

36. Gordon, C. M.; Holbrey, J. D.; Kennedy, A. R.; Seddon, K. R.; J. Mater. Chem. 1998, 8, 2627.

37. Herrmann, W. A.; Goossen, L. J.; J. Artus, G. R.; Kocher, C.; Organometallics 1997, 16, 2472.

38. Martin, J. D.; ACS Symp. Ser. 2002, 818, 413.

39. Cang, H.; Li, J.; Fayer, M. D.; J. Chem. Phys. 2003, 119, 13017.

40. Tait, S.; Osteryoung, R. A.; Inorg. Chem. 1984, 23, 4352; Dieter, M. K.; Dymek Jr., C. J.; Heimer, N. E.; Rovang, J. W.; Wilkes, J. S.; J. Am. Chem. Soc. 1988, 110, 2722.

41. Fannin Jr., A. A.; King, L. A.; Levisky, J. A.; Wilkes ,J. S.; J. Phys. Chem. 1984, 88, 2609; Wilkes, J. S.; Frye, J. S.; Reynolds, G. F.; Inorg. Chem. 1983, 22, 3870.

42. Heimer, N. E.; Del Sesto, R. E.; Carper, W. R.; Magn. Reson.Chem. 2004, 42, 71.

43. Gannon, T. J.; Law, G.; Watson, P. R.; Carmichael, A. J.; Seddon, K. R.; Langmuir 1999, 15, 8429.

44. Hardacre, C.; Holbrey, J. D.; McMath, S. E. J.; Bowron, D. T.; Soper, A. K.; J. Chem. Phys. 2003, 118, 273.

45. Biggin, S.; Enderby, J. E.; J. Phys. C-Solid State Phys. 1982, 15, L305; Rovere, M.; Tosi, M. P.; Rep. Prog. Phys. 1986, 49, 1001.

46. Hayashi, S.; Ozawa, R.; Hamaguchi, H.; Chem. Lett. 2003, 32, 498-499; Ozawa, R.; Hayashi, S.; Saha, S.; Kobayashi, A.; Hamaguchi, H.; Chem. Lett. 2003, 32, 948.

47. AbdulSada, A. K.; Elaiwi, A. E.; Greenway, A. M.; Seddon, K. R.; Europ. Mass Spect. 1997, 3, 245. 
48. Gozzo, F. C.; Consorti, C. S.; Dupont, J.; Eberlin, M. N.; Chem. Eur. J., 2004, in press.

49. Holbrey, J. D.; Reichert, W. M.; Nieuwenhuyzen, M.; Sheppard, O.; Hardacre, C.; Rogers, R. D.; Chem. Commun. 2003, 476.

50. Anthony, J. L.; Maginn, E. J.; Brennecke, J. F.; J. Phys. Chem. B 2002, 106, 7315.

51. For a simulation study see: Hanke, C. G.; Johansson, A.; Harper, J. B.; Lynden-Bell, R. M.; Chem. Phys. Lett. 2003, 374, 85.

52. See for example: Abbott, A. P.; Schiffrin, D. J.; J. Chem. Soc. Faraday Trans. 1990, 1453; Ue ,M.; Electrochim. Acta 1994, 39, 2083.

53. Cammarata, L.; Kazarian, S. G.; Salter, P. A.; Welton, T.; Phys. Chem. Chem. Phys. 2001, 3, 5192.

54. For an elegant work on the hydrogen bond interaction of the imidazolium cation with dienes in the control of a reaction selectivity see: Aggarwal, A.; Lancaster, N. L.; Sethi, A. R.; Welton, T.; Green Chem. 2002, 4, 517.

55. Consorti, C. S.; Suarez, P. A. Z.; de Souza, R. F.; Burrow, R. A.; Loh, W.; da Silva, L. H. M.; Dupont, J.; unpublished results.

56. Previous conductivities studies of ionic liquid plus water and organic solvents have been performed using relatively high ionic liquid concentrations: Zhang, J.; Wu, W.; Jiang, T.; Gao, H.; Liu, Z.; He, J.; Han, B.; J. Chem. Eng. Data 2003, 48, 1315; Hagiwara, R.; Ito, Y.; J. Fluor. Chem. 2000, 105, 221.

57. Zhang, J. M.; Yang, C. H.; Hou, Z. S.; Han, B. X.; Jiang, T.; Li, X. H.; Zhao, G. Y.; Li, Y. F.; Liu, Z. M.; Zhao, D. B.; Kou, Y.; New J. Chem. 2003, 27, 333.

58. Ally, M. R.; Braunstein, J.; Baltus, R. E.; Dai, S.; DePaoli, D. W.; Simonson, J. M.; Ind. Eng. Chem. Res. 2004, 43, 1296.

59. Avent, A. G.; Chaloner, P. A.; Day, M. P.; Seddon, K. R.; Welton, T.; J. Chem. Soc. Dalton Trans. 1994, 3405-3413.
60. Dupont, J.; Suarez, P. A. Z.; de Souza, R. F.; Burrow, R. A.; Kintzinger, J. P.; Chem. Eur. J. 2000, 6, 2377.

61. Huang, J.-F.; Chen, P.-Y.; Sun, I-W.;.Wang, S. P.; Inorg. Chim. Acta 2001, 320, 7; Huang, J. F.; Chen, P. Y.; Sun, I. W.; Wang, S. P.; Spectrosc. Lett. 2001, 34, 591.

62. Mele, A.; Tran, C. D.; Lacerda, S. H. P.; Angew. Chem. Int. Ed. 2003, 42, 4364.

63. Schroder, U.; Wadhawan, J. D.; Compton, R. G.; Marken, F.; Suarez, P. A. Z.; Consorti, C. S.; de Souza, R. F.; Dupont, J.; New J. Chem. 2000, 24, 1009.

64. See for example: Elliott, J. M.; Attard, G. S.; Bartlett, P. N.; Owen, J. R.; Ryan, N.; Singh, G.; J. New Mater. Electrochem. Syst. 1999, 2, 239; Attard, G. S.; Bartlett, P. N.; Coleman, N. R. B.; Elliott, J. M.; Owen, J. R.; Langmuir 1998, 14, 7340; Attard, G. S.; Bartlett, P. N.; Coleman, N. R. B.; Elliott, J. M.; Owen, J. R.; Wang, J. H.; Science 1997, 278, 838.

65. Scheeren, C. W.; Machado, G.; Dupont, J.; Fichtner, P. F. P.; Texeira, S. R.; I norg. Chem. 2003, 42, 4738.

66. Anderson, J. L.; Pino, V.; Hagberg, E. C.; Shereas, V. V.; Armstrong, D. W.; Chem. Commun. 2003, 2444.

67. See for example: Binks, B. P.; Dyab, A. K. F.; Fletcher, P. D. I.; Chem. Commun. 2003, 2540 and For an earlier example see: Willert, M.; Rothe, R.; Landfester, K.; Antonietti, M.; Chem. Mater. 2001, 13, 4681.

68. See for example: Bronger, R. P. J.; Silva, S. M.; Kamer, P. C. J.; van Leeuwen, P. W. N. M.; Chem. Commun. 2002, 3044.

69. Swatloski, R. P.; Spear, S. K.; Holbrey, J. D.; Rogers, R. D.; J. Am. Chem. Soc. 2002, 124, 4974.

Received: March 23, 2004

Published on the web: May 10, 2004 